\title{
The Effect Green Marketing Mix on Corporate Image as Well as Implication for Purchase Intention of Food and Beverages Companies In Indonesia
}

\author{
Ryan Johan Sembiring \\ Universitas Persada Indonesia Y.A.I, Indonesia. \\ Email: ryanjohansembiring@yahoo.com
}

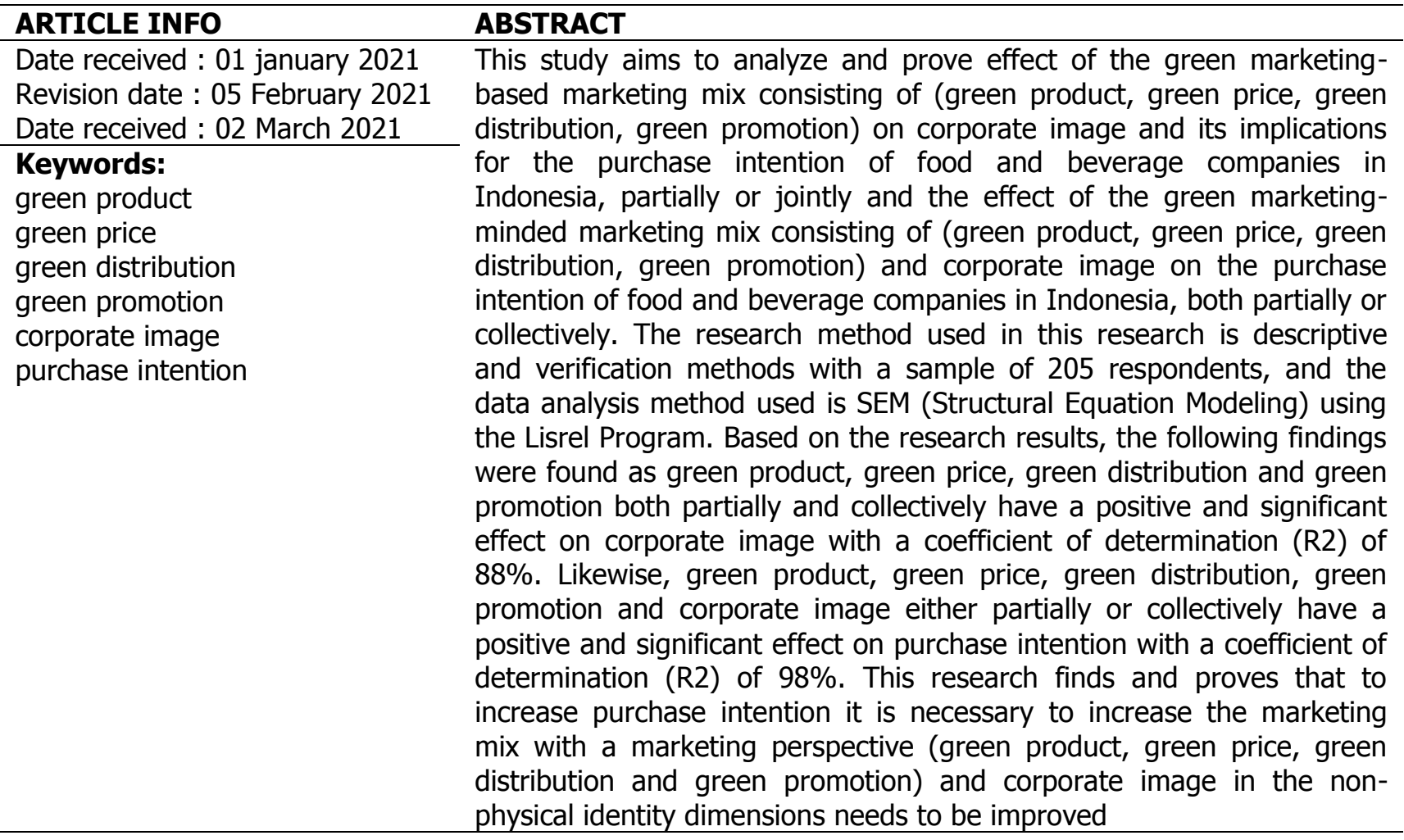

Coresponden Author:

Email: ryanjohansembiring@yahoo.com Article with open access under license

\section{INTRODUCTION}

Environmental preservation has received important attention and is starting to be realized by the world community. Environmental damage results in environmental disasters, not only health but even human survival. Environmental damage that has occurred cannot be avoided, but if people around the world are determined not to carry out activities and also not to use products that can damage the environment, it is considered that it can reduce environmental damage. Such a situation eventually arises what is called green consumerism

Green consumerism is a continuation of the global consumerism movement that began with 
consumer awareness of their rights to obtain products that are feasible, safe, and environmentally friendly products.

Likewise, consumers in Indonesia are starting to realize the importance of environmental conservation. Indonesian consumers support the environmental conservation movement by purchasing environmentally friendly products. Consumers who have environmental awareness are often called green orientation, which is predicted to increase in the future. Consumers who have a high awareness of the environment will choose products that are environmentally friendly even though the price is relatively more expensive. The increasing public awareness about the importance of preserving the environment has made many producers and companies start to switch to using materials that do not damage the environment or other terms environmentally friendly materials.

With public awareness about the environment, the company must be able to implement environmental issues as one of its marketing strategies. The concept of product marketing that uses ingredients that do not damage the environment is now known as green marketing. When several companies use green marketing as the axis of their successful marketing strategy, from then on, green marketing has begun to become the main focus of business for various companies.

This research was conducted in food and beverage companies, i.e. PT Nestle Indonesia, PT Indofood CBP Sukses Makmur Tbk and PT Unilever Indonesia Tbk. This food and beverage company has a variety of brands that are well known among Indonesian consumers. The company is also implementing a green marketing mix strategy to strengthen its corporate image and to attract consumer buying interest. One of the efforts taken is to offer products that are environmentally friendly and committed to participating in preserving the environment.

Based on the growth rate and number of companies in the food and beverage industry, companies that want to grow and win the competition can use green marketing as a marketing strategy to strengthen their corporate image and attract consumer buying interest (purchase intention) of the products offered.

Consumer purchase interest is a consumer behavior in which consumers have the desire to buy or choose a product, based on experience in choosing, using and consuming or even wanting a product (Kotler, Philip and Keller, 2012).

In this study, consumers' purchase intention (purchase intention) is influenced by the corporate image (company image) and the green marketing mix which consists of green products, green prices, green promotions and green distribution.

Company image is a reflection of the identity of an organization or company, in which a company is able to have several different images in the eyes of the public (Kasali, 2009: 30). Company image is the image of ideas, thoughts and impressions of the position and shows that the company image is the perception of the company. The company image reflects the company's performance which is formed in the memory of consumers.

Company that has a good image in the eyes of consumers will influence consumer choices in making purchases. At that time consumers will remember that the company has a good reputation and quality so that consumers will make purchases for the company's products. In this case, a good company image will have an effect on consumer buying interest. It can be said that company image can influence consumer purchase interest.

Likewise, consumer buying interest is reflected in the increase in company sales, which can be influenced by building a corporate image during the process of business development.

The corporate image in this study is influenced by the green marketing mix which consists of green product, green price, green promotion, and green distribution.

Green products are products that are manufactured using non-toxic materials and environmentally friendly process steps, and which are certified by a recognized organization (Kumar \& Ghodeswar, 2015).

Green price is a price that refers to a certain price in company policies relating to environmental considerations set by regulations and company instructions or initiatives. However, green products often require a higher initial cost but in the long run will be economical (Cullington \& Zeng, 2011).

Green promotion involves the configuration of promotional tools, such as advertising, marketing materials, signs, white papers, websites, public relations, sales promotion, direct marketing and onsite promotion, videos and presentations keeping people, planet and profits in mind. (Shil, 2012).

Green distribution is a very complicated operation. The customer must be assured of the 'ecological nature' of the product. A green environment is a constantly regulated environment and therefore a high level of compliance is essential when distributing green products (Rashad Yazdanifard \& Mercy, 2011).

The green marketing mix strategy that is implemented properly by the company is expected 
to affect the increase in corporate image and also influence consumer buying interest in green products offered by the company.

Research on the green marketing mix and consumer buying interest has been carried out by many previous researchers with different results among researchers causing a research gap. Gap research allows other researchers to do research again with a similar theme, for that the authors are interested in re-examining the green marketing mix, and consumer buying interest by adding corporate image as an intervening variable.

\section{Literature Research Green Marketing}

Green Marketing is a process of marketing and producing goods or services that prioritize environmental friendliness. Green Marketing should be done by all companies in the world, because now our environment is getting worse due to Global Warming.

Green marketing is a concept, which includes all marketing activities developed to stimulate and sustain consumers' eco-friendly attitudes and behaviors. Green marketing is a concept, which includes all marketing activities that are developed to stimulate and maintain consumer environmental friendly behavior attitudes (Tuma, $\mathrm{J}$. M., \& Pratt, J. M. (1982). Clinical child psychology practice and training: A survey. VIots of Clinical Child \& Adolescent Psychology, 137(August 2012) et al., 2002). The term green marketing became known in the late 1980s and early 1990s, but it turned out that this had been discussed earlier. The American Marketing Associate (AMA) in 1975 held the first seminar on "Ecological Marketing" and produced a book on green marketing entitled "Ecological Marketing" (RUDI HARYADI, 2009).

(Ottman et al., 2006) argues that the dimensions of green marketing, by integrating the environment into all aspects of marketing, new product development (green product) and communication (green communication). The goals of green marketing are to improve the relationship between industry and the environment, to monitor the impact of the economy, and to respond to government regulations on the environment.

Polonsky (Wu \& Chen, 2014) defines green marketing as all activities designed by companies in order to meet human needs by reducing adverse impacts on the environment.

\section{Green Product}

Products are central to the eco-friendly marketing mix and the most important part of a green marketing strategy. However, it must be considered in the brain that green products are not limited to the last object but involve all elements of the product, such as the materials used, the production process, the product package and others. (Cullington \& Zeng, 2011).

(Junaedi, 2015) states that green products are products that are not harmful to humans and the environment, are not wasteful of resources, do not produce excessive waste, and do not involve cruelty to animals. Green products must consider environmental aspects in the product life cycle so as to minimize negative impacts on nature. This minimization effort is to encourage all parties to play a role in technology development towards environmentally friendly products. In the production sector, various ways can be done to produce an environmentally friendly product, one of which is by using the concept of a sustainable green product.

(Kumar \& Ghodeswar, 2015) state that an environmentally friendly product is a product that is manufactured using environmentally friendly measures and non-toxic ingredients licensed by a well-known company. Nugrahadi (2002: 219) argues, green products are products that are environmentally friendly. A product that is designed and processed in a way to reduce the effects that can pollute the environment, both in production, distribution and consumption.

\section{Green Price}

(Kalama, 2007) states that price is the cost paid for a product. This is an essential element of the marketing mix. The majority of consumers will only be prepared to pay a premium if there is a perception of the value of the additional product. According to (Hashem \& Al-Rifai, 2011), green price refers to a certain price in company policies relating to environmental considerations set by company regulations and instructions or its initiatives.

Price of environmentally friendly products must be reasonable for consumers who inspire them to buy environmentally friendly products ( $R$ Yazdanifard \& Mercy, 2011). Most consumers will only be prepared to pay high if there is an opinion about the added value of green products (Kalama, 2007). Price is an important and important factor of green marketing integration. Green products often have a higher price than traditional products. Most of them contain higher primary output costs, but lower long-run costs. Most consumers are only ready to pay higher prices when they get the added value of the product. Green products must be kept in a balance between consumers who pay a fee and 
the approval of the satisfaction of paying more for environmental safety (Saremi et al., 2014).

\section{Green Distribution/Place}

Green place is about managing logistics to reduce transportation emissions, so that it basically aims to reduce the carbon footprint (Shil, 2012). With regard to distribution gates associated with green products, which are suitable for customers, in terms of facilitating their delivery, and for securing cycling procedures carried out under environmental conditions and requirements (Hashem \& Al-Rifai, 2011).

Delivery method is a consolidated association between the company and the consumer. In the environmental marketing delivery scheme referred to as a green place is a dissemination gate that facilitates distribution and to safeguard the process carried out in conservation conditions and needs (Hashem \& Al-Rifai, 2011).

Place represents the location where a product can be purchased. This can mean physical or virtual stores. Product distribution must be from satisfactory channels, and clearly and properly placed in an environmentally safe place where there is no contamination whatsoever. In order for green businesses to be established and to be priced competitively, companies must ensure that their distributors care about the environment and establish that they set a green distribution strategy (Kalama, 2007).

Green distribution is a very complicated operation. The customer must be assured of the 'ecological nature' of the product. A green environment is a constantly regulated environment and therefore a high level of compliance is essential when distributing green products (Rashad Yazdanifard \& Mercy, 2011).

\section{Green Promotion}

Green promotion involves the configuration of promotional tools, such as advertising, marketing materials, signs, white papers, websites, public relations, sales promotion, direct marketing and onsite promotion, videos and presentations keeping people, planet and profits in mind (Shil, 2012). A significant promotional tool is green advertising as a promotional message that can attract the wants and desires of consumers who care about the environment (Ankit \& Mayur, 2013).

Green advertising according to Davis in Ozkocak (2011: 2) is that green advertising must provide concrete benefits to the environment and the characteristics of the message so that it can be distinguished from other advertisements.
Green promotion refers to transferring real ecological information to consumers who participate in company activities. In addition, the company's promise to safeguard natural assets is to determine which target audience is attractive (Shirsavar \& Fashkhamy, 2013). Green promotion means promoting the actual transfer of environmental information to consumers with activities related to company activities. The actual promotion of a product or company requires a change in the product, process, or focus of participation (such as a non-strategic change). There is a lot of concern among consumers about environmental campaigns. The right way to deal with this problem is to focus on continuous communication rather than using the limited concept of limited green promotion. Ongoing communication places great emphasis on verbal formation to stakeholders, especially customers, and aims to raise awareness and training to strengthen the social and environmental reputation of the company and its products.

Company image is the image of ideas, thoughts and impressions of the position and shows that the company image is the perception of the company. The company image reflects the company's performance which is formed in the memory of consumers. The image of corporate social responsibility can have a positive effect on the image of the company and in society. A company that is committed to economic development, ethics within the organization, supporting employees and their families, supporting non-profit groups and providing for the needs of society, has a much better image in the minds of society than other companies (Pomering \& Dolnicar, 2009).

Image is the most important asset of a company. A good image is a powerful tool to attract consumers to choose the company's products or services, but also improve consumer satisfaction with the company or organization (Sutojo, 2011: 60). Image provides a positive assessment and existence of the company in the eyes of the public, namely by showing the public's view of the company in the long term. A well-formed image will have a good impact on the achievement of the goals set by the company.

\section{Purchase Intention}

(Durianto, 2013) states that buying interest is the desire to own a product, buying interest will arise when a consumer is affected by the quality and quality of a product, information about the product, ex: price, how to buy and the weaknesses and advantages of the product compared to other brands. . 
According to (Arslan \& Zaman, 2014) purchase interest can be defined as a possibility; a consumer will buy a product or service in the future. Positive purchase intentions encourage consumers to actual purchase action or negative purchase intentions discourage consumers from buying them.

(Schiffman \& Kanuk, 2000) say that interest is one of the psychological aspects that has a considerable effect on behavioral attitudes. Purchase interest can be interpreted as a happy attitude towards an object that makes individuals try to get that object by paying for it with money or sacrifice.

Consumer purchase interest is a consumer behavior in which consumers have the desire to buy or choose a product, based on experience in choosing, using and consuming or even wanting a product (Kotler, Philip and Keller, 2012).

(Simamora, 2001) states that buying interest (purchase intention) for a product arises because of the basic trust in the product accompanied by the ability to buy the product. In addition, the purchase intention of a product can also occur with the effect of other people who are trusted by potential customers. Purchase intention can also arise when a consumer is very interested in various information about a product obtained through advertising, the experiences of people who have used it, and an urgent need for a product.

\section{METHOD}

The method used in this research is descriptive and verification research methods. This research is intended to build a real picture of a phenomenon that is in the context of the research. With this descriptive research, various information will be collected in order to test hypotheses or answer questions concerning research problems.

Verification research basically tests the truth through data collection in the field. The nature of verification basically wants to test the truth of a hypothesis which is carried out through data collection in the field. The verification research aims to determine the effect of the green product variables, green price, green distribution, green promotion, corporate image and purchase intention.

To study all research problems, the required data were obtained through a field survey using a questionnaire. Then analysis and descriptions of all research problems were carried out through data analysis, statistical calculations and data interpretation.

\section{Operational Variables}

Definition of variables according to (Sugiyono, 2013) is an attribute or nature or value of an object or activity that has certain variations that are applied by researchers to study and then draw conclusions.

Variables in this study consist of independent variables, namely green product, green price, green distribution, green promotion and dependent variables, namely corporate image and purchase intention. Each variable is measured in a Likert scale score which is arranged based on a 5 (five) scale or a Likert scale which is implemented in five options, namely: SS (Strongly Agree), has a score of 5, S (Agree), has a score of 4, KS (Less Agree), has a score of 3, TS (Disagree), has a score of 2 , and STS (Strongly Disagrees), has a score of 1.

Population in this study was taken from all consumers who consume or use products from food and beverage companies (PT Nestle Indonesia, PT Indofood CBP Sukses Makmur Tbk, PT Unilever Indonesia Tbk, and PT Ultra Jaya) in the DKI Jakarta area.

In this study, the sample size was adjusted to the analytical model used, namely structural equation modeling (SEM). In this regard, the sample size for SEM using the maximum likelihood (MLE) estimation model is $100-200$ samples (Santoso et al., 2014).

Referring to (Gronemus et al., 2010) found that the appropriate sample size is 100 to 200. It is also explained that the minimum sample size is 5 observations for each estimated parameter and the maximum is 10 observations from each estimated parameter. In this study, the number of research indicators was 41 , so the minimum sample size was 5 times the estimated number of indicators or $5 \mathrm{x}$ $41=205$. The number of samples used was more, i.e. 215 , so that if there is biased or invalid data then it is does not reduce the number of respondents below the minimum sample suggested by (Gronemus et al., 2010).

Sampling technique uses purposive sampling method, which is a sampling method based on certain criteria or considerations. In this case the sample is selected based on consumers over 17 years of age who use food and beverage company products in the Jakarta area.

\section{Data Analysis}

To analyze the effect of green product, green price, green promotion, green distribution on corporate image and its implications for the purchase intention of a food and beverage company in Jakarta, which was carried out using SEM 
(Structural Equation Model) analysis using the Lisrel 8.80 program.

Comprehensive analysis of all variables in the study at the multivariate analysis stage was carried out by structural equation modeling (Structural Equation Model / SEM). In general, SEM analysis techniques are divided into 2 main characteristics, namely: 1) the estimation of multiple interdependence of many variables; and 2) the ability to present unobserved concepts in these relationships by involving measures of deviation (error) in the estimation process (Santoso et al., 2014).

This is similarly stated by (Jöreskog, 1973) in (Santoso et al., 2014) which states that the SEM analysis technique consists of 2 parts, i.e.: 1) the measurement section, which connects the observed variable (which is often referred to as the manifest variable) to the latent variable ( which is often referred to as construct variables) through a confirmatory factor model, and 2) structural parts, which connect between construct variables through a system of simultaneous equations. Estimation of model parameters uses the maximum likelihood estimation.

\section{RESULTS AND DISCUSSION}

Model feasibility testing is carried out in order to achieve a good model and meet the GOF requirements on Structural Equation Modeling, the complete SEM model can be seen in the following figure.

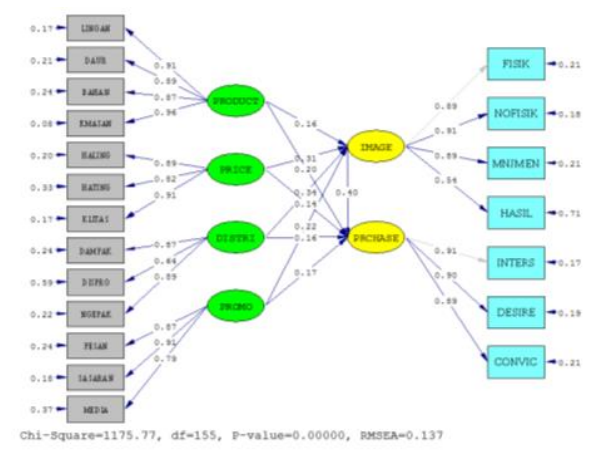

Full Model Path Diagram (Standardized Solution)

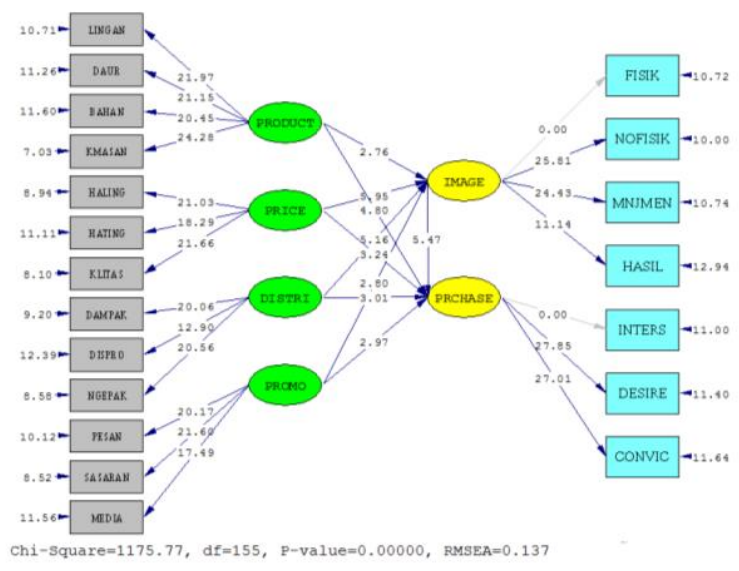

Full Model Path Diagram ( $T$-Values)

In Structural Equation Modeling there is no single statistical test tool to measure or test the model created, generally there are various types of fit indexes that are used to measure the degree of conformity between the hypothesized model and the data presented. Therefore, based on the full model path diagram above, to be able to analyze the research hypothesis it is necessary to test the suitability of the overall model (Goodness of Fit Index Full Model Structural). The GOF evaluation of the research model can be seen in the following table.

Table 1. Goodness of Fit Index Full Model

\begin{tabular}{|c|c|c|c|c|}
\hline No & Ukuran GOF & Tingkat Kecocokan & Hasil & Kesimpulan \\
\hline 1 & $\begin{array}{c}\text { Chi-Square }\left(\chi^{2}\right) \\
\mathrm{P}>0,05\end{array}$ & $\begin{array}{c}\text { Diharapkan kecil } \\
\mathrm{p} \geq 0,05\end{array}$ & $\begin{array}{c}1175,77 \\
\mathrm{P}=0,005\end{array}$ & Marginal \\
\hline 2 & RMSEA & $\leq 0,08$ & 0,137 & Marginal \\
\hline 3 & NFI & $\geq 0,90$ & 0,95 & Baik \\
\hline 4 & PNFI & Diharapkan Tinggi & 0,77 & Baik \\
\hline 5 & CFI & $\geq 0,90$ & 0,95 & Baik \\
\hline 6 & IFI & $\geq 0,90$ & 0,95 & Baik \\
\hline 7 & RMR & $\geq 0,05$ & 0,072 & Marginal \\
\hline 8 & GFI & $\geq 0,90$ & 0,75 & Marginal \\
\hline
\end{tabular}

Source: Wijanto, 2015 and Results of Lisrel 8.80 Processing

If seen in the table above, all the estimated goodness fit structural models have a good value even though there are some marginal ones such as Chi-Square and GFI, but overall the estimated structural models are acceptable, so it can be said that the relationship between various constructs on this variable is a structural relationship. . This can be justified in the opinion of (Gronemus et al., 2010) that the use of 4 - 5 goodness of fit criteria is considered sufficient to assess the feasibility of a 
model, provided that each of the criteria for goodness of fit is absolute fit indices, incremental fit indices, and parsimony fit indices. represented.

Based on the results of hypothesis testing, it is found that all hypotheses are proven to be accepted. The overall results of hypothesis testing can be seen briefly as follows:

Table 2. Summary of Hyphotesys Testing Results

\begin{tabular}{|c|c|c|c|c|c|}
\hline Hyphotesis & Path & $\begin{array}{c}\text { Path } \\
\text { Coeff } \mathrm{R}^{2}\end{array}$ & T-Value & F-Value & Remarks \\
\hline $\mathrm{H}_{1}$ & PD $\rightarrow$ CM & 0,16 & 2,76 & & Received \\
\hline $\mathrm{H}_{2}$ & PC $\rightarrow$ CM & 0,31 & 5,95 & & Received \\
\hline $\mathrm{H}_{3}$ & DB $\rightarrow$ CM & 0,34 & 5,16 & & Received \\
\hline $\mathrm{H}_{4}$ & PM $\rightarrow$ CM & 0,22 & 2,80 & & Received \\
\hline $\mathrm{H}_{5}$ & $\begin{array}{c}\text { PD, PC, DB, PM } \rightarrow \\
\text { CM }\end{array}$ & 0,88 & & 6,45 & Received \\
\hline $\mathrm{H}_{6}$ & PD $\rightarrow$ PI & 0,20 & 4,80 & & Received \\
\hline $\mathrm{H}_{7}$ & PC $\rightarrow$ PI & 0,14 & 3,24 & & Received \\
\hline $\mathrm{H}_{8}$ & $\mathrm{DB} \rightarrow \mathrm{PI}$ & 0,16 & 3,01 & & Received \\
\hline $\mathrm{H}_{9}$ & PM $\rightarrow$ PI & 0,17 & 2,97 & & Received \\
\hline $\mathrm{H}_{10}$ & $\mathrm{CM} \rightarrow \mathrm{PI}$ & 0,40 & 5,47 & & Received \\
\hline $\mathrm{H}_{11}$ & $\begin{array}{c}\text { PD, PC, DB, PM, } \\
\mathrm{CM} \rightarrow \text { PI }\end{array}$ & 0,98 & & 1,56 & Received \\
\hline
\end{tabular}

Based on the table above, all of the seven hypotheses proposed in this study can be accepted, either directly or indirectly. Meanwhile, the structural equation results from the research variables can be seen from the output of lisrel in Structural Equations.

Equation of Substructure 1

\section{IMAGE $=0.16 *$ PRODUCT $+0.31 *$ PRICE + $0.34 *$ DISTRI + 0.22*PROMO, Errorvar.$=0.12$ , $\mathbf{R}^{2}=0.88$}

Equation of Substructure 2

\section{PRCHASE $=0.40 *$ IMAGE $+0.20 *$ PRODUCT + $0.14 *$ PRICE + 0.16*DISTRI + 0.17*PROMO, Errorvar. $=0.015, R^{2}=0.98$}

For substructure equation 1 , namely corporate image is significantly influenced by green product, green price, green distribution and green promotion. The contribution of the four independent variables to corporate image is $88 \%$, so there are still $12 \%$ other factors that affect corporate image but are not examined.

For substructure equation 2, namely purchase intention is significantly and positively influenced by corporate image, green product, green price, green distribution, green promotion and corporate image. The contribution of the five independent variables to purchase intention is $98 \%$, so there are still $2 \%$ other factors that affect purchase intention but are not researched.

Based on the results of hypothesis testing and discussion of theories in previous chapters, the following discussions and interpretations are carried out:

\section{Effect of Green Product on Corporate Image}

Based on the research results, the $t$-value is $2.76>1.96$ so that $\mathrm{Ho}$ is rejected and $\mathrm{H} 1$ is accepted, which means that there is a positive effect of green product on corporate image. The path coefficient / R2 is 0.16 , which means the magnitude of the effect of green product on corporate image is $16 \%$ and the remaining $89 \%$ is another factor not examined.

Green product is a product that is not harmful to humans and the environment, does not waste resources, does not produce excessive waste, and does not involve cruelty to animals (Junaedi, 2005). While the corporate image or corporate image is a reflection of the identity of an organization or company Kasali (2012) in (Subagja \& Susanto, 2019)

Green products are environmentally friendly products made by companies. Eco-friendly products are ecologically safe products that can facilitate the long-term goal of protecting and preserving natural habitats, namely, environmentally friendly products or environmental awareness products, which are referred to as products designed to reduce the consumption of natural resources needed and minimize the environmental impact that is harm through the entire life cycle of these items (Tseng \& Hung, 2013).

Environmentally friendly products offered by the company to consumers and proven to be completely free from toxins, safe for consumption or use can enhance the company's image. Environmentally friendly products are not only limited to products but product packaging is also considered by consumers whether the packaging is not harmful to the environment, can be recycled. Consumers will always remember the company's image when using or consuming the products offered by the company.

Results of this study are in line with research conducted by (Mallek, 2016), (Folasayo, 2019) which states that green products can affect corporate image or corporate image. 


\section{Effect of Green Price on Corporate Image}

Based on the research results, the $t$-value is $5.95>1.96$ so that $\mathrm{Ho}$ is rejected and $\mathrm{H} 2$ is accepted, which means there is a positive effect of green price on corporate image. The path coefficient / R2 is 0.31 , which means that effect of green price on corporate image is $31 \%$ and the remaining $69 \%$ is another factor not examined.

Price is an important element in the marketing mix, most customers are willing to pay a premium price if there is additional perception in the product. This increase in value can be caused by performance, function, design, attractive shape or taste. Environmental advantages are only an added bonus, but are often the determining factor between product value and quality.

Consumers who care about environmental sustainability will always remember the company's image, and will continue to remember even though the price of environmentally friendly products offered is more expensive than conventional products.

Results of this study support the research conducted by (Mallek, 2016), (Folasayo, 2019), which states that green prices can affect corporate image.

\section{Effect of Green Distribution on Corporate Image}

Based on the research results, the t-value is $5.16>1.96$ so that $\mathrm{Ho}$ is rejected and H3 is accepted, which means there is a positive effect of green distribution on the corporate image. The path coefficient / R2 is 0.34 which means that the magnitude of the effect of green product on corporate image is $34 \%$ and the remaining $66 \%$ is another factor not examined.

Green distribution can be done by utilizing retailers or distributors appropriately. For example, to support a packaging recycling program, companies can work with retailers to encourage consumers to return packaging through them, in exchange for souvenirs, discounted prices, vouchers, or promotional products. Green distribution that is done well and can minimize the impact on environmental damage can improve the company's image in the eyes of consumers.

The results of this study support the research conducted by (Mallek, 2016), (Folasayo, 2019) which states that green promotion can affect corporate image.

\section{Effect of Green Promotion on Corporate Image}

Based on the research results obtained $\mathrm{t}$ value $2.80>1.96$ so that $\mathrm{Ho}$ is rejected and $\mathrm{H} 4$ is accepted, which means there is a positive effect of green promotion on corporate image. The path coefficient / R2 is 0.22 which means the magnitude of the effect of green promotion on corporate image is $22 \%$ and the remaining $78 \%$ is another factor not examined.

Green promotion carried out by companies must pay attention to the relationship between products and the environment, the lifestyle of using or consuming green products, presenting the company's image through social responsibility activities. Green promotion of company activities to campaign for programs that raise environmental issues to strengthen the image as an environmentally friendly company. This promotion can be done through advertisements, logos on labels, sales promotions (through packaging), or public relations

Green promotion that is carried out well and right on target will always remember and associate with the company's image in the eyes of consumers, and will increase in line with the fact that the environmentally friendly products offered truly meet consumer expectations.

Results of this study support the research conducted by (Mallek, 2016), (Folasayo, 2019) which states that green promotion can affect corporate image.

Effect of Green Product, Green Price, Green Distribution and Green Promotion Simultaneously On Corporate Image in Food and Beverage Companies in Indonesia.

The green marketing mix which includes green products that are made and produced is in accordance with the concept of environmentally friendly, green prices offered are in accordance with green products, green distribution that supports the environment and green promotion that is done well by the company, it can simultaneously affect the image Food and Beverage company.

Effect of Green Product on Purchase Intention Based on the research results, the t-value is $4.80>1.96$ so that $\mathrm{Ho}$ is rejected and $\mathrm{H} 6$ is accepted, which means that there is a positive effect of green product on purchase intention. The path coefficient / R2 is 0.20 , which means that the effect of green product on purchase intention is $20 \%$ and the remaining $80 \%$ is another factor not examined. 
Green products or environmentally friendly products are how the products produced by companies can answer various problems faced by the macro environment, for example waste, pollution, the ozone layer, global warming, nutrition, health. So that the company produces products that can be recycled, energy efficient, non-CFCs, noncholesterol

Green products or environmentally friendly products including packaging offered by companies with various advantages of the products they have compared to conventional products can attract consumers to try and buy environmentally friendly products offered by companies.

Results of this study are in line with research conducted by (Thoria O Mahmoud, 2018), (Thoria Omer Mahmoud et al., 2017), Shrestha, Shulov. (2016), (Maichum et al., 2017), (Zhu, 2012), (Ansar, 2013), (Wu \& Chen, 2014) (Mankiw, 2012) which state that green products can affect purchase intention.

Effect of Green Price on Purchase Intention

Based on the research results, the $t$-value is $3.24>1.96$ so that $\mathrm{Ho}$ is rejected and $\mathrm{H} 7$ is accepted, which means that there is a positive effect of green price on purchase intention. The path coefficient / R2 is 0.14 , which means the magnitude of the effect of green price on purchase intention is $14 \%$ and the remaining $86 \%$ is another factor not examined.

Green price considers people, planet and profit in methods that safeguard the health of employees and society and ensure efficient productivity. Value can be added to it by changing its appearance, functionality and through customization, etc. (Gaidhani et al., 2019).

Green price offered for environmentally friendly products to consumers becomes a consumer's consideration even though the price is relatively high compared to conventional prices, but consumers who care about environmental sustainability can understand the prices offered by the company and are still interested in making purchases. This is done by consumers as a form of their support for environmental sustainability.

Results of this study support research conducted by (Thoria O Mahmoud, 2018), (Thoria Omer Mahmoud et al., 2017), Shrestha, Shulov. (2016), (Maichum et al., 2017), (Zhu, 2012), (Ansar, 2013), (Wu \& Chen, 2014) (Mankiw, 2012) who state that green prices can affect purchase intention.
Intention

Effect of Green Distribution on Purchase

Based on the research results, the $t$-value is $3.01>1.96$ so that $\mathrm{Ho}$ is rejected and $\mathrm{H} 8$ is accepted, which means that there is a positive effect of green distribution on purchase intention. The path coefficient / R2 is 0.16 which means the magnitude of the effect of green distribution on purchase intention is $16 \%$ and the remaining $84 \%$ is another factor that is not examined.

Green distribution is a location where a product can be purchased. This can mean physical or virtual stores. Product distribution must be from satisfactory channels, and clearly and properly placed in an environmentally safe place where there is no contamination whatsoever. For a green business to be established and to be priced competitively, companies must ensure that their distributors care about the environment and establish that they set a green distribution strategy (Goldman, 2012).

Distribution carried out by companies with due regard to the impact on environmental damage, such as packing goods using wood materials, will affect the consumer's view of the products that the company offers and can also influence consumer purchase interest.

Results of this study support research conducted by (Thoria O Mahmoud, 2018), (Thoria Omer Mahmoud et al., 2017), Shrestha, Shulov. (2016), (Maichum et al., 2017), (Zhu, 2012), (Ansar, 2013), (Wu \& Chen, 2014) (Mankiw, 2012) who state that green distribution affects purchase intention. Intention

Effect of Green Promotion on Purchase

Based on the research results, the t-value is $2.97>1.96$ so that $\mathrm{Ho}$ is rejected and $\mathrm{H} 9$ is accepted, which means that there is a positive effect of green promotion on purchase intention. Path coefficient / R2 is 0.17 which means the magnitude of the effect of green promotion on purchase intention is $17 \%$ and the remaining $83 \%$ is another factor not examined.

Green promotion involves and communicates information about environmental commitments and efforts made by companies to consumers. This element in the green marketing mix includes various activities such as paid advertising, public relations, sales promotion, direct marketing, and on-site promotion (Fan and Zeng, 2011).

Green promotion that is carried out well and informs clearly about environmentally friendly 
products, starting from the raw material for the product itself, packaging, distribution, raising environmental issues that companies do with the community to strengthen its image as an environmentally friendly company can attract the attention of consumers and are interested in doing purchase.

Results of this study support research conducted by (Thoria O Mahmoud, 2018), (Thoria Omer Mahmoud et al., 2017), Shrestha, Shulov. (2016), (Maichum et al., 2017), (Zhu, 2012), (Ansar, 2013), (Wu \& Chen, 2014) (Mankiw, 2012) which state that green promotion can affect purchase intention.

Intention

Effect of Corporate Image on Purchase

Based on the research results, the t-value is $5.47>1.96$ so that $\mathrm{Ho}$ is rejected and H9 is accepted, which means that there is a positive effect on corporate image on purchase intention. The path coefficient / R2 is 0.40 , which means that the effect of corporate image on purchase intention is $40 \%$ and the remaining $60 \%$ is another factor not examined.

Company image is a reflection of the identity of an organization or company, in which a company is able to have several different images in the eyes of the public (Kasali, 2009: 30). Company image is the image of ideas, thoughts and impressions of the position and shows that the company image is the perception of the company. The company image reflects the company's performance which is formed in the memory of consumers.

Companies that have a good image in the eyes of consumers will influence consumer choices in making purchases. At that time consumers will remember that the company has a good reputation and quality so that consumers will make purchases for the company's products. In this case, a good company image will have an effect on consumer buying interest. It can be said that company image can affect consumer buying.

Results of this study support the research conducted by (Ronaldo et al., 2018), (Kijpanjasub \& Jitkuekul, 2019), (Chao \& Liao, 2016) which state that corporate image can affect purchase intention.

Effect of Green Product, Green Price, Green Distribution, Green Promotion dan Corporate Image Simultaneously on Purchase Intention in Food and Beverage Companies in Indonesia

Green marketing mix which includes the green products offered is truly environmentally friendly, the green price is in accordance with the green product, green distribution that supports the environment, green promotion that is well done by the company and the corporate image that has been formed in consumers simultaneously affect purchase intention of Food and Beverage companies.

\section{CONCLUSION}

Based on the results of research that has been conducted on the effect of the marketing mix with green marketing insight (green product, green price, green distribution and green promotion) on corporate image and its implications for the purchase intention of food and beverage company products in Indonesia and the discussion in previous chapters and based In the results of statistical calculations using the SEM (Structural Equation Model) model and using the Lisrel version 8.8 program, several conclusions can be made as follows:

1. There is effect of green product on corporate image in food and beverage companies in Indonesia.

2. There is effect of green price on corporate image in food and beverage companies in Indonesia.

3. There is effect of green distribution on corporate image in food and beverage companies in Indonesia.

4. There is effect of green promotion on corporate image in food and beverage companies in Indonesia.

5. There is effect green product, green price, green distribution and green promotion simultaneously on corporate image in food and beverage companies in Indonesia.

6. There is effect of green product on purchase intention in food and beverage companies in Indonesia.

7. There is effect of green price on purchase intention in food and beverage companies in Indonesia.

8. There is effect of green distribution on purchase intention in food and beverage companies in Indonesia.

9. There is effect of green promotion on purchase intention in food and beverage companies in Indonesia.

10. There is effect of corporate image on purchase intention in food and beverage companies in Indonesia.

11. There is effect of green product, green price, green distribution, green promotion and corporate image simultaneously on purchase 
intention in food and beverage companies in Indonesia.

\section{REFERENCES}

Ankit, G., \& Mayur, R. (2013). Green marketing: Impact of green advertising on consumer purchase intention. Advances in Management, 6(9), 14.

Ansar, N. (2013). Impact of green marketing on consumer purchase intention. Mediterranean Journal of Social Sciences, 4(11), 650.

Arslan, M., \& Zaman, R. (2014). Impact of Brand Image and Service Quality on Consumer Purchase Intention: A Study of Retail Store in Pakistan. 4(22), 2225-2484.

Chao, R., \& Liao, P.-C. (2016). The Impact of Brand Image and Discounted Price on Purchase Intention in Outlet Mall : Consumer Attitude as Mediator. The Journal of Global Business Management, 12(2), 119-128.

Cullington, H. E., \& Zeng, F.-G. (2011). Comparison of bimodal and bilateral cochlear implant users on speech recognition with competing talker, music perception, affective prosody discrimination and talker identification. Ear and Hearing, 32(1), 16.

Durianto, D. S. \& T. S. (2013). Strategi Menaklukkan Pasar Melalui Riset Ekuitas dan Perilaku Merek.

Folasayo, A. M. (2019). Green Marketing and Perceived Corporate Image: A Study of Fast Moving Consumer Goods in Lagos State Nigeria. International Journal of Academic Research in Business and Social Sciences, 9(7), 202-224. https://doi.org/10.6007/ijarbss/v9-i7/6110

Gaidhani, S., Arora, L., \& Sharma, B. K. (2019). Understanding the attitude of generation Z towards workplace. International Journal of Management, Technology And Engineering, 9, 2804-2812.

Goldman, E. (2012). How Zappos' User Agreement Failed In Court and Left Zappos Legally Naked. Forbes-Http://Www. Forbes. Com/Sites/Ericgoldman/2012/10/10/HowZappos-User-Agreement-Failed-in-CourtandLeft-Zappos-Legally-Naked.

Gronemus, J. Q., Hair, P. S., Crawford, K. B., Nyalwidhe, J. O., Cunnion, K. M., \& Krishna, N. K. (2010). Potent inhibition of the classical pathway of complement by a novel C1qbinding peptide derived from the human astrovirus coat protein. Molecular Immunology, 48(1-3), 305-313.

Hashem, T. N., \& Al-Rifai, N. A. (2011). The influence of applying green marketing mix by chemical industries companies in three Arab States in West Asia on consumer's mental image. International Journal of Business and Social Science, 2(3).

Jöreskog, K. G. (1973). Analysis of covariance structures. In Multivariate analysis-III (pp. 263-285). Elsevier.

Junaedi, M. F. S. (2015). Pengaruh kesadaran lingkungan pada niat beli produk hijau: Studi perilaku konsumen berwawasan lingkungan. Benefit: Jurnal Manajemen Dan Bisnis, 9(2), 189-201.

Kalama, E. (2007). Green marketing practices by Kenya petroleum refineries: a study of the perception of the management of oil marketing companies in Kenya. University of NAIROBI.

Kijpanjasub, K., \& Jitkuekul, P. (2019). Corporate Reputation And Corporate Image Influence Customer Purchase Intentions And Loyalty Of Lowcost Airlines. International Academic Multidisciplinary Research Conference In Vienna 2019.

Kotler, Philip and Keller, K. L. (2012). Manajemen Pemasaran. Erlangga.

Kumar, P., \& Ghodeswar, B. M. (2015). Factors affecting consumers' green product purchase decisions. Marketing Intelligence \& Planning.

Mahmoud, Thoria O. (2018). Impact of green marketing mix on purchase intention. International Journal of Advanced and Applied Sciences, 5(2), 127-135.

Mahmoud, Thoria Omer, Ibrahim, S. B., Ali, A. H., \& Bleady, A. (2017). The influence of green marketing mix on purchase intention: The mediation role of environmental knowledge. International Journal of Scientific \& Engineering Research, 8(9), 1040-1048.

Maichum, K., Parichatnon, S., \& Peng, K.-C. (2017). Factors affecting on purchase intention towards green products: A case study of young consumers in Thailand. Young, 16, 17.

Mallek, M. (2016). The Green Marketing Functions based on Image of Company in the Retail Environment. International Journal of Humanities and Cultural Studies, Internet $v$, $575-582$.

Mankiw, N. G. (2012). Principles of macroeconomics 6th edition. Thompson South-Western Cengage. 
Ottman, J. A., Stafford, E. R., \& Hartman, C. L. (2006). Avoiding green marketing myopia: Ways to improve consumer appeal for environmentally preferable products. Environment: Science and Policy for Sustainable Development, 48(5), 22-36.

Pomering, A., \& Dolnicar, S. (2009). Assessing the prerequisite of successful CSR implementation: are consumers aware of CSR initiatives? Journal of Business Ethics, 85(2), 285-301.

Ronaldo, R., Maulina, E., Alexandri, M. B., Purnomo, M., Fadoli, \& Yulmaulini. (2018). Corporate image on purchase intention, mediated by trust and commitment on the loss insurance industry in Indonesia. International Journal of Management and Business Research, 8(3), 142-153.

RUDI HARYADI, R. H. (2009). Pengaruh strategi green marketing terhadap pilihan konsumen melalui pendekatan marketing mix (Studi kasus pada The Body Shop Jakarta). Program Pasca Sarjana Universitas Diponegoro.

Santoso, E. B., Erli, H. K. D. M., Aulia, B. U., \& Ghozali, A. (2014). Concept of carrying capacity: Challenges in spatial planning (Case study of East Java Province, Indonesia). Procedia-Social and Behavioral Sciences, 135, 130-135.

Saremi, H., Nezhad, B. M., \& Tavakoli, M. (2014). A study on impact of green marketing mixed on consumers purchasing behavior-case study on consumers of dairy products in scientific \& applied education center bicycle production complex of Quchan, Iran. Ecology, Environment and Conservation, 20(3), 13431352.

Schiffman, L. G., \& Kanuk, L. L. (2000). Consumer behavior, 7th. NY: Prentice Hall, 15-36.

Shil, P. (2012). Evolution and future of environmental marketing. Asia Pacific Journal of Marketing \& Management Review, 1(3), 7481.

Shirsavar, H. A., \& Fashkhamy, F. (2013). Green marketing: A new paradigm to gain competitive advantage in contemporary business. Trends in Advanced Science and Engineering, 7(1), 12-18.

Simamora, B. (2001). Memenangkan pasar dengan pemasaran efektif dan profitabel. Jakarta. Gramedia Pustaka Utama.

Subagja, I. K., \& Susanto, P. H. (2019). Pengaruh Kualitas Pelayanan, Kepuasan Nasabah Dan Citra Perusahaan Terhadap Loyalitas
Nasabah Pt. Bank Central Asia Tbk Kantor Cabang Pondok Gede Plaza. Jurnal Manajemen Bisnis Krisnadwipayana, 7(1).

Sugiyono, P. D. (2013). Metode penelitian kuantitatif dan kualitatif dan R\&D [Quantitative and qualitative and $R$ \& $D$ research methods]. Bandung, Indonesia: Alfabeta.

Tseng, S.-C., \& Hung, S.-W. (2013). A framework identifying the gaps between customers' expectations and their perceptions in green products. Journal of Cleaner Production, 59, 174-184.

Tuma, J. M., \& Pratt, J. M. (1982). Clinical child psychology practice and training: A survey. Vdots of Clinical Child \& Adolescent Psychology, 137(August 2012), 37-41. http://doi.org/10.1037/a0022390, Gobry, F. (1999). $\{$ T $\}$ his is a title. $\{$ M $\}$ y Journal, $1,120-$ 130., Osment, S. E. (1980). T. A. of R. 12501550 ... and R. H. of L. M. and R. ... R. from http://scholar. google. $\mathrm{com} /$ scholar?hl=en\&btnG=Search\&q=intitle:TH $\mathrm{E}+\mathrm{AGE}+\mathrm{OF}+\mathrm{REFORM}+125$.-

1550\#2\%5Cnhttp://scholar. google. com/scholar?hl=en\&btnG=S., Caprara, G., \& Fida, R. (2008). Longitudinal analysis of the role of perceived self-efficacy for self-regulated learning in academic continuance and achievement. ... of Educational ..., 100(3), 525-534. http://doi.org/10.1037/00220663.100.3.525, Shanker, S. (2003). Philosophy of science, logic and mathematics in the twentieth century. ... P. L. and N. Y. R. http://doi. org/10. 4324/978020302947., Marenbon, J. (1998). R. H. of P. I. ... P. L. and N. Y. R. http://doi. org/10. 4324/978020306227., Pole, N., \& Ablon, J. (2002). Ideal control mastery technique correlates with change in a single case. ... Theory, Research, Practice ..., 39(1), 88-96. http://doi.org/10.1037//0033-3204.39.1.88, Xu, S., \& Rajlich, V. (2005). Dialog-based protocol: An empirical research method for cognitive activities in software engineering. 2005 International Symposium on Empirical Software Engineering, ISESE 2005, 397-406. http://doi.org/10.1109/ISESE.2005.1541848,

Polikovsky, S., Kameda, Y., \& Ohta, Y. (2009). Facial micro-expressions recognition using high speed camera and 3D-gradient descriptor. 3rd International Conference on Imaging for Crime Detection and Prevention (ICDP 2009), (February), P. http://doi. org/10. 1049/ic. 2009. 024., Papadimitriou, A., \& Cai, Y. (2011). What drives the choice of mixed methods designs? - An analysis of current higher education research publications. 7 th 
Mixed Methods International Conference, (June)., Dunbar, K. N. (1998). Problem solving. A Companion to Cognitive Science, 289-298. Retrieved from http://psycnet.apa.org/psycinfo/1987-98523-

000, Kimin, A. (2012). The focusing-oriented approach applied to couple therapy. A Thesis Submitted for the Degree of Ph.D in the School of Education and Lifelong Learning, University of East Anglia, (June), 553., Explicit, M. I. (n. d. ). T. knowledge M. I. E. A. T. for T. F., Williams, L. L., Levine, J. B., Malhotra, S., \& Holtzheimer, P. (2004). The good-enough mentoring relationship. Acad. Psychiatry, 28(2),

111-115. http://doi.org/10.1176/appi.ap.28.2.111, Falzer, P. R., \& Garman, D. M. (2012). Evidencebased decision-making as a practice-based learning skill: a pilot study. Acad. Psychiatry, 36(2), 104-109. http://doi.org/10.1176/appi.ap.10050082,

Carraccio, C. L., Benson, B. J., Nixon, L. J., \& Derstine, P. L. (2008). From the educational bench to the clinical bedside: translating the Dreyfus developmental model to the learning of clinical skills. Academic Medicine: Journal of the Association of, 761-767. http://doi.org/10.1097/ACM.0b013e31817eb63 2, Feinstein, R. E., \& Yager, J. (2013). Advanced psychotherapy training: Psychotherapy scholars' track, and the apprenticeship model. Academic Psychiatry, $37(4)$, 248-253. http://doi.org/10.1176/appi.ap.12100174,

Suddaby, R. O. Y. (2006). From the Editors:
Academy of Management Journal, 49(4), 633642., Thompson, M. (2011). Ontological shift or ontological drift? Reality claims, epistemological frameworks, and theory generation in organization studies. Academy of Management Review, 36(4), 754-773. http://doi.org/10.5465/amr.2010.0070, Keshav, S. (2007). How to Read a Paper. Work, 37(3), 83-84. http://doi.org/10.1145/1273445.1273458.

(2002). Middlesex University Doctor of Professional Studies. Studies in Higher Education.

Wu, S.-I., \& Chen, Y.-J. (2014). The impact of green marketing and perceived innovation on purchase intention for green products. International Journal of Marketing Studies, 6(5), 81.

Yazdanifard, R, \& Mercy, I. E. (2011). The impact of Green Marketing on Customer satisfaction and Envi- ronmental safety.

Yazdanifard, Rashad, \& Mercy, I. E. (2011). The impact of green marketing on customer satisfaction and environmental safety. 2011 International Conference on Computer Communication and Management, 5(1), 637641.

Zhu, B. (2012). The Impact of Green Advertising on Consumer Purchase Intention of Green Products. SSRN Electronic Journal. https://doi.org/10.2139/ssrn.2182906 